\title{
CHEMICAL INTERACTION BETWEEN Struthanthus marginatus (Desr.) Blume AND TWO DIFFERENT HOSTS
}

\author{
Aline Moreira de Siqueira1*, Izabela Taiana Salazar Rogério', \\ Bruno Conde Esteves', Luciana Moreira Chedier ${ }^{1}$, \\ Arthur Ladeira Macedo², Daniel Sales Pimenta ${ }^{1}$ \\ 'Universidade Federal de Juiz de Fora, MG \\ ¿Universidade Federal Fluminense, Niterói, RJ \\ *E-mail: alinemds1@yahoo.com.br
}

Recebido em: 24/062015 Aceito em: 19/05/2016 Publicado em: 31/12/2016

\begin{abstract}
Struthanthus marginatus (Desr.) Blume ("erva de passarinho"), Loranthaceae is a hemiparasitic species known for its popular use for respiratory tract infections. However, caution should be taken when using this plant, noting the possible presence of harmful components to health originating from their hosts. The aim of this study is to anatomically analyze it and evaluate $S$. marginatus hemiparasitic phytochemistry on hosts Dombeya wallichii Benth. \& Hook ("dombeia") and Morus rubra L. (blackberry) in order to compare if there is chemical variation influenced by hosts on the hemiparasitic species. For the phytochemical analysis, there were hexanic and methanolic extractions of S. marginatus leaves and stalks, as well as the stems of the hosts. The extracts were analyzed by GC/MS and HPLC, besides a thin layer chromatography performance. The analysis of the leaf extracts showed that $\bigotimes$-amyrin is the only compound found in S. marginatus leaves over D. wallichii. By HPLC only two similar compounds were detected and three different compounds to the parasite leaves comparatively analyzed in the two hosts. The analysis of the hexane extract revealed seven-like compounds in leaves of both herbs, and in S. marginatus leaves collected on D. wallichii are compounds with greater intensity, in addition to establishing the presence of two more compounds. These results suggest the occurrence of chemical variation influenced by the host, which is important for understanding the relationship between $S$. marginatus and their hosts and for the plant quality control.
\end{abstract}

Keywords: Hemiparasitic, Host, Medicinal plant, Struthanthus marginatus.

\section{Interação química entre Struthanthus marginatus (Desr.) Blume e dois hospedeiros diferentes}

\section{Resumo}

Struthanthus marginatus (Desr.) Blume (erva de passarinho) - Loranthaceae, é uma espécie hemiparasita conhecida por ser uma planta medicinal de uso popular para infecções das vias respiratórias. Alguns cuidados devem ser observados ao se utilizar essa planta como recurso terapêutico, atentando para a possível presença de substâncias tóxicas originadas de seus hospedeiros. Analisou-se a anatomia e avaliou-se a fitoquímica do hemiparasitismo de S. marginatus sobre os hospedeiros: Dombeya wallichii Benth. \& Hook (dombéia) e Morus rubra L. (amora-negra), a fim de comparar se há variação química influenciada pelos hospedeiros sobre a espécie hemiparasita. Para as análises fitoquímicas, foram realizadas extrações hexânicas e metanólicas das folhas e caules de $S$. marginatus, assim como os caules dos hospedeiros. Os extratos analisados por CG-EM e CLAE, além da realização de cromatografia em camada fina. As análises do extrato hexânico revelaram que há sete substâncias semelhantes nas folhas das ervas, sendo que na erva coletada sobre $D$. wallichii, as substâncias estão com maior intensidade, e, além disso, constatou-se a presença de duas substâncias a mais. Na análise dos extratos hexânicos, $\alpha$-amirina foi encontrada apenas na folha de $S$. marginatus sobre $D$. wallichii, sendo um possível indicador de diferença química influenciada pelos hospedeiros. O resultado do extrato metanólico mostrou semelhanças entre as folhas dos parasitas, com presença de flavonoides, além 
de substâncias químicas observadas apenas em S. marginatus sobre $D$. wallichii, mostrando, também, variação química em hospedeiros diferentes.

Palavras-Chave: Hemiparasitismo, Hospedeiro, Planta medicinal, Struthanthus marginatus.

\section{Interacción química entre Struthanthus marginatus (Desr.) Blume y dos hospederos diferentes}

\section{Resumen}

Struthanthus marginatus (Desr.) Blume (erva de passarinho) - Loranthaceae, el muérdago es una especie conocida por ser una planta de uso popular para infecciones del tracto respiratorio. Algunos cuidados deben ser observados cuando se utiliza esa planta como recurso terapéutico, poniendo atención especial en la posible presencia de sustancias tóxicas provenientes de sus hospederos. Se analizó la anatomía y se examinó la fitoquímica del hemiparaistismo de S. marginatus sobre los hospederos:

Dombeya wallichii Benth. Y Hook (dombéia) y Morus rubra L. (zarzamora, negro), con el objetivo de comparar si hay variación química influenciada por los hospederos sobre la especie muérdago.Para el análisis fitoquímico se realizaron extracciones hexânicas de las hojas y tallos de S. marginatus, y de los tallos de los hospederos. Los extractos analisados por CG-EM y CLAE, además de La realización de cromatografía en camada fina. El análisis del extracto hexánico reveló que hay siete sustancias semejantes en las hojas de las hiervas, siendo que en la hierva colectada sobre D. wallichii, las sustancias están con mayor intensidad, y, a parte de eso, se verificó la presencia de dos sustancias más. En el análisis de los extractos hexánicos, $\square-$ amirina se encontró apenas una hoja de $S$. marginatus sobre $D$. wallichii, siendo un posible indicador de diferencia química influenciada por los hospederos. El resultado del extracto metanólico indicó semejanzas entre las hojas de los parásitos, con presencia de flavonoides, además de, sustancias químicas observadas solamente en S. marginatus sobre D. wallichii, presentando, también, variación química en hospedeiros diferentes.

Palabras-clave: Hemiparasitismo, Hospedero, Planta medicinal, Struthanthus marginatus.

\section{INTRODUCTION}

Species of Loranthaceae are recognized for they medicinal properties(1). This family that includes 70 genus and 800 species and has a pantropical distribution. In Brazil, there are around 10 genus and 100 species. All species are hemiparasites and are popularly known as erva de passarinho (mistletoe) due to their dependence on birds to deposit their seeds on the branches of other trees(2).

Hemiparasitic plants generally have a root structure known as haustorium, which penetrates the xylem to remove water and nutrients from the host to ensure their photosynthetic activity ${ }^{(3)}$. In some species however the penetration of haustoria can reach only the phloem ${ }^{(4)}$, which can generate a contamination with metabolites of the host.

Struthanthus marginatus (Desr.) Blume (Loranthaceae) is a medicinal plant that was included in the $1^{\text {st }}$ edition of the Brazilian Pharmacopoeia by its popular use against infections in respiratory tract, such as bronchitis and pneumonia, and as decongestant in cough ${ }^{(5)}$. Despite this, there are reports of poisoning by the tea of $S$. marginatus parasitizing a Datura suaveolens Humb, \& Bonpl. The authors showed that atropine and other alkaloids were present in the ethanolic extract from both species. Once these alkaloids were never isolated before and are not common in S. marginatus, it is suggested that these compounds were absorbed by the haustorium of S. marginatus(6). 
The aims of the present study are: (a) to analyze the anatomical structure of the haustorium of S. marginatus parasitizing two different hosts: Morus rubra L. (Moraceae) and Dombeya wallichii Benth. \& Hook (Malvaceae) and (b) to evaluate the characteristics of the extracts of the hosts and parasite.

\section{METHODS}

\section{Plant material}

Leaves and stems of S. marginatus, M. rubra and D. wallichii were collected at the Instituto de Ciências Biológicas, Universidade Federal de Juiz de Fora, with the vouchers deposited in the CESJ Herbarium under the numbers 54338,54339 and 6009. Many hosts as parasites were under the same environmental conditions of climate and soil.

\section{Histological anatomy}

For anatomical analysis, freehand cross sections of branches were made of both parasitized hosts classical methodology as plant anatomy, using double staining with Astra blue and $\operatorname{safranin}^{(7,8)}$.

\section{Extractions}

Plants were extracted by static maceration with $n$-hexane and methanol ACS grade (Sigma-Aldrich) successively, until exhaustion. The extracts made are show in Table 1.

Table 1. List of the extracts made of Struthanthus marginatus, Morus rubra, Dombeya wallichii

\begin{tabular}{|c|c|c|c|}
\hline Plant & Solvent & Part & Extract \\
\hline \multirow{4}{*}{$\begin{array}{l}\text { Struthanthus marginatus parasitizing } \\
\text { Morus rubra }\end{array}$} & \multirow{2}{*}{ Hexane } & Leaves & $\mathrm{SMHL}$ \\
\hline & & Stem & SMHS \\
\hline & \multirow{2}{*}{ Methanol } & Leaves & SMML \\
\hline & & Stem & SMMS \\
\hline \multirow{4}{*}{$\begin{array}{l}\text { Struthanthus marginatus parasitizing } \\
\text { Dombeya wallichii }\end{array}$} & \multirow{2}{*}{ Hexane } & Leaves & $\mathrm{SDHL}$ \\
\hline & & Stem & SDHS \\
\hline & \multirow{2}{*}{ Methanol } & Leaves & SDML \\
\hline & & Stem & SDMS \\
\hline \multirow{4}{*}{ Morus rubra } & \multirow{2}{*}{ Hexane } & Xylem & $\mathrm{MHX}$ \\
\hline & & Phloem & $\mathrm{MHP}$ \\
\hline & \multirow{2}{*}{ Methanol } & Xylem & MMX \\
\hline & & Phloem & MMP \\
\hline
\end{tabular}

continua... 


\begin{tabular}{|llll|}
\hline Plant & Solvent & \multicolumn{1}{l|}{ Part } & Extract \\
\hline \multirow{3}{*}{ Dombeya wallichii } & \multirow{2}{*}{ Hexane } & \multicolumn{1}{c|}{ Xylem } & DHX \\
\cline { 2 - 4 } & & Phloem & DHP \\
\cline { 2 - 4 } & \multirow{2}{*}{ Methanol } & Xylem & DMX \\
\cline { 2 - 4 } & & Phloem & DMP \\
\hline
\end{tabular}

Source: Elaborated by the authors.

\section{TLC analysis}

Thin layer chromatography analyses were performed in Alugram SIL G/UV ${ }_{254}$ plates (Macherey-Nagel, Düren, Germany). The solvent system was hexane: ethyl acetate (9:1) for hexanic extracts and ethyl acetate: methanol (8:2) for methanolic extracts, and the chemical revelators were sulfuric vanillin and resublimed iodine.

The same solvent concentrations were used in all tests to allow comparisons among results with the same intensity.

\section{Gas chromatography/Mass spectrometry, GC/MS}

This analysis was carried out using a Hewlett Packard 6890 gas chromatograph equipped with a fused silica capillary column (HP-5, $30 \mathrm{~m} \times 0.25 \mathrm{~mm}, 0.25 \mu \mathrm{m}$ film thickness), helium as carrier gas with a flow rate $1.0 \mathrm{~mL} / \mathrm{min}$; temperature programming from $70^{\circ} \mathrm{C}$ to $290^{\circ} \mathrm{C}\left(2^{\circ} \mathrm{C} / \mathrm{min}\right)$, coupled to a Hewlett-Packard 5972 mass spectrometer. The MS operating parameters were $70 \mathrm{eV}$, ion source $250^{\circ} \mathrm{C}$ equipped with El.

\section{HPLC analysis}

Chemical profiles of samples were obtained by HPLC-DAD, in a Shimadzu (Kyoto, Japan) equipment with two LC-10AD pumps, DGU-12A degasser, SIL-10AD automatic injector, and SPD-M10AVP diode array detector (DAD). Data were collected by a SCL-10A interface controlled by the Shimadzu CLASS-VP 6.13 SP2 version software.

Samples were diluted to obtain a concentration of $2 \mathrm{mg} / \mathrm{mL}$. $20 \mu \mathrm{L}$ of each sample were injected in a Supelcosil - C18 column ( $250 \mathrm{~mm} \times 46 \mathrm{~mm}-5 \mu \mathrm{m})$, with a Supelcoguard - LC18 guard column $(2 \mathrm{~cm})$. The solvent system was a $0.05 \%$ trifluoroacetic acid aqueous solution (A) and acetonitrile HPLC grade (B). The system was put in a gradient from 5 to $65 \%$ of $B$ $(0-60 \mathrm{~min}), 65$ to $100 \%$ of $B(60-70 \mathrm{~min})$, maintaining $100 \%$ of B $(70-80 \mathrm{~min})$ with a flow rate of $1 \mathrm{~mL} / \mathrm{min}$. The monitoring was conducted with a DAD detector sweeping between 200 e $400 \mathrm{~nm}$, with the wavelengths of 220, 270, 335 and $360 \mathrm{~nm}$ being selected.

\section{RESULTS}

\section{Histological anatomy}

The lengthwise anatomical cut insertion haustorium of S. marginatus in the stem of the host (Figure 1) shows the interface in the phloem stratified in the outer portion, and inside the xylem. The haustorium is seen in the central part of Picture A, trespassing phloem. 
Figure 1. Histological sections showing the hemiparasitic Struthanthus marginatus
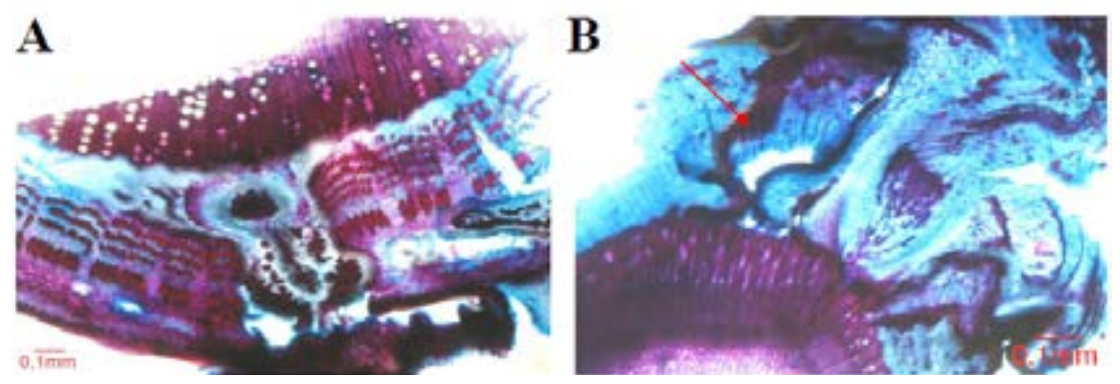

Fig. 1: A) Longitudinal view of the haustorium Struthanthus marginatus parasitizing the stem of Dombeya wallichii seen in cross section. B) Longitudinal view of the haustorium Struthanthus marginatus parasitizing the stems of Morus rubra seen in cross section (arrow in B indicates the lignified barrier).

Source: Elaborated by the authors.

\section{Hexanic extracts}

TLC analyses showed difference between SDHL and SDHS, and the latter showed a greater chemical variety. The analysis of the plates at $365 \mathrm{~nm}$ showed seven compounds in SMHL and nine in SDHL.

In TLC, the extracts of hosts xylems did not show identified similar compounds, and D. wallichii xylem with greater fluorescence intensity. The plates of hexane extracts revealed with resublimed iodine showed similar compounds in the leaves of both parasites, although with less intensity.

Table 2 shows the chemical constituents found in the leaf extracts of different species, identified by GC/MS.

Table 2. Comparison chemistry between hosts and parasites.

\begin{tabular}{|c|c|c|c|}
\hline & Exclusive of $D$. wallichi & Exclusive of $M$. rubra & Common in both \\
\hline \multirow[t]{2}{*}{ Host phloem } & - & $\begin{array}{l}\text { Cis- } \beta \text {-amyrin-acetate; } \\
\text { Naphthoquinone; } \\
\text { Trans- } \beta \text {-amyrin-acetate }\end{array}$ & - \\
\hline & $4\left(\mathrm{RT}=3.05^{\prime}\right)$ & $3\left(\mathrm{RT}=2.06^{\prime}\right)$ & $5\left(\mathrm{RT}=3.7^{\prime}\right)$ \\
\hline \multirow[t]{2}{*}{ Host xylem } & 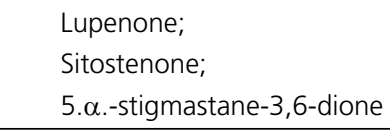 & Gamma sitosterol & - \\
\hline & $\begin{array}{l}1\left(\mathrm{RT}=1.15^{\prime}\right) ; 2\left(\mathrm{RT}=1.95^{\prime}\right) \\
6\left(\mathrm{RR}=9.8^{\prime}\right)\end{array}$ & $3\left(\mathrm{RT}=2.06^{\prime}\right) ; 4\left(\mathrm{RT}=3.05^{\prime}\right) ; 5\left(\mathrm{RT}=3.7^{\prime}\right)$ & - \\
\hline
\end{tabular}

continua... 


\begin{tabular}{|c|c|c|c|}
\hline \multirow{2}{*}{$\begin{array}{l}\text { S. } \\
\text { marginatus } \\
\text { stalk }\end{array}$} & $\begin{array}{l}\text { Nonacosane; } \\
\beta \text {-amyrin; } \\
\text { Lupenone; Lupenol; }\end{array}$ & - & - \\
\hline & $\begin{array}{l}7\left(\mathrm{RT}=14.37^{\prime}\right) \\
8\left(\mathrm{RT}=16.93^{\prime}\right)\end{array}$ & $4\left(\mathrm{RT}=3.05^{\prime}\right) ; 6\left(\mathrm{RT}=9.8^{\prime}\right)$ & $\begin{array}{l}1\left(R T=1.15^{\prime}\right) ; 2 \\
\left(R T=1.95^{\prime}\right) ; F 1 \\
\left(R T=14.37^{\prime}\right)\end{array}$ \\
\hline \multirow{2}{*}{$\begin{array}{l}\text { S. } \\
\text { marginatus } \\
\text { leaf }\end{array}$} & $\alpha$-amyrin & - & $\begin{array}{l}\text { Nonacosane; } \\
\beta \text {-amyrin; } \\
\text { Lupenol }\end{array}$ \\
\hline & $\begin{array}{l}2\left(R T=1.95^{\prime}\right) ; 7\left(R T=14.37^{\prime}\right), 8 \\
\left(R T=16.93^{\prime}\right)\end{array}$ & $3\left(\mathrm{RT}=2.06^{\prime}\right) ; 4\left(\mathrm{RT}=3.05^{\prime}\right) ; 6\left(\mathrm{RT}=9.8^{\prime}\right)$ & $\begin{array}{l}F 2\left(R T=15.99^{\prime}\right) ; \\
F 3\left(R T=16.70^{\prime}\right)\end{array}$ \\
\hline
\end{tabular}

The results in the first line refer to the analysis by GC -MS and the second line to HPLC analysis. Each number indicates a different compound evaluated by UV and TR. F corresponds to the probable chemical flavonoid group and ( _ _ ) means that the compound was not detected. RT = Retention time.

Source: Elaborated by the authors.

\section{Methanolic extracts}

Table 2 highlights the difference between the chemical methanolic extracts of phloem and xylem of both hosts, with only a similar compound, called $5\left(T R=3.7^{\prime}\right)$. Although different hosts showed different chemical characteristics, a similarity between the parasite leaves was found for the presence of a likely flavonoid group detected by UV being represented by F1 (TR $\left.=14,37^{\prime}\right)$, F2 $\left(\mathrm{RT}=1599^{\prime}\right)$ and F3 $\left(\mathrm{TR}=16.70^{\prime}\right)$.

The compounds represented by the numbers $7\left(T R=14.37^{\prime}\right)$ and $8\left(T R=16.93^{\prime}\right)$ were found only in $S$. marginatus parasitizing $D$. wallichii, showing the chemical variation in different hosts, and the compound number 3 (TR $=2.066^{\prime}$ ) in $S$. marginatus parasitizing $M$. rubra.

\section{DISCUSSION}

The anatomical sections showed that the root of the parasite goes through the xylem of the host plant. However, some species of Loranthaceae may have a decrease in their vegetative share and penetrate only in the phloem ${ }^{(10)}$. There is also a possibility of contamination if its host has some toxic substance.

Comparisons of the results obtained by thin layer chromatography (TLC) and GC/MS were done to associate the common compounds in each analysis, considering that both analyzed hexanic extracts. The CCD analysis of the hexanic extracts of S. marginatus on hosts under a 365nm UV light, showed marked differences between the stem extracts of both parasites when considering the intensity and the amount of the compound.

The extracts from S. marginatus leaves presented different compounds, corroborating the analysis done by GC/MS. $\alpha$-amyrin $\left(T R=70.2^{\prime}\right)$ was present in the extract of $S$. marginatus collected on $D$. wallichii but was not present in the leaf of the 
parasite collected on $M$. rubra, suggesting a changing in the chemical composition of the parasitic plant according to its host. $\alpha$-amyrin has anti-inflammatory properties, inhibiting the activity of some kinases proteins .

The stems of $S$. marginatus collected on $D$. wallichii revealed more compounds than the other parasite, as seen in the results of GC/MS below, in which compounds as nonacosane $\left(R T=61^{\prime}\right), \beta$-amyrin $\left(R T=69.3^{\prime}\right)$; lupenone $\left(R T=69.7^{\prime}\right)$ and lupenol $\left(T R=70.3^{\prime}\right)$ were identified in this analysis. Lupenol has a chemopreventive and chemotherapeutic potential in human cells(11).

In this analysis (Table 2), similar compounds were identified, nonacosane, $\beta$-amyrin and lupenol, in the leaves of both parasites and stem of $S$. marginatus parasitizing $D$. wallichii, indicating that the production of such compounds possibly did not influence by varying the host. In contrast, $\alpha$-amyrin was found only in $S$. marginatus leaves on $D$. wallichii, indicating a possible chemical interference by the host. Similar compounds were not observed in the phloem and xylem between the two hosts.

The results of CCD analysis in methanolic extracts were compared to the results of HPLC, because both analyzed methanolic extracts. The analysis in TLC under UV light $365 \mathrm{~nm}$ of S. marginatus methanolic extract on hosts revealed that extracts of $S$. marginatus leaves have a similar profile. However, when comparing these results to HPLC, one realizes that there really is such a compound, which is represented by $2\left(T R=1.95^{\prime}\right)$ in Table 2 . There was the presence of $2\left(T R=1.95^{\prime}\right)$ in $S$. marginatus leaves on $M$. rubra, revealing that parasite plants do not possess all similar chemical constituents, which could be related to the hosts interference.

The HPLC results showed that the phloem of the hosts were not entirely equivalent regarding the chemical composition, but they had a common compound, represented by the number $5\left(T R=3.7^{\prime}\right)$, as seen in Table 2 .

The hemiparasitic relation shown in Picture 1 was chemically confirmed by GC/MS and HPLC (Table 2) to appear in the presence of the parasite compounds present only on the xylem of the respective host, when compared to those detected on the phloem.

Chemical results corroborate the hemiparasitic relationship between $S$. marginatus and the hosts observing gifts substances of the xylem hosts appear leaves and stems of their herbs. The chemical variation among the parasites suggests to hosts care exchange, being thus relevant for the quality control of this plant.

\section{Acknowledgment}

We would like to thank the Programa de Pós-Graduação em Ecologia Aplicada à Conservação da Biodiversidade (PGECOLUFJF), the university extension program Produção de Plantas Medicinais e Fitoterapia (PROEX-UFJF), CAPES, and the Plataforma Analítica Framanguinhos/FIOCRUZ for their support.

\section{REFERENCES}

1. Vieira OMC, Santos MH, Silva GA, Siqueira A. Atividade antimicrobiana de Struthanthus vulgaris (erva de passarinho), Alfenas, MG. Rev. Bras. Farmacognosia. 2005; 15(2): 149-154.

2. Souza VC, Lorenzi H. Botânica Sistemática. Guia ilustrado para identificação das famílias de Angiospermas da flora brasileira, baseado em APG II. Instituto Plantarum de Estudos da Flora Ltda; 2005. p. 512.

3. Dettke GA, Gutierre MMA. Estudo anatômico dos órgãos vegetativos da hemiparasita Phoradendron mucronatum (DC.) Krug \& Urb. (Viscaceae). Rev Bras Biocs. 2007; 5(1): 534 - 536. 
4. Medel R, Botto-Mahan C, Smith-Ramirez C, Men MA, Ossa CG, Caputo L, Gonzales WL. Historia natural e cuantitativa de uma relacion parasito-hospedeiro: el sistema Tristerix-cactáceas em Chile semiárido. Rev Chil Hist Nat. 2002; 3(75): 127140.

5. Pharmacopoeia dos Estados Unidos do Brasil. 1926. $1^{\mathrm{a}}$ ed. São Paulo: Companhia Editora Nacional.

6. Martins LGS, Vale LS, Lainetti R, Pereira NA. Um estudo sobre a toxicidade de erva-de-passarinho (Struthanthus marginatus (Desr.) Blume, Loranthaceae), parasitando trombeteira (Datura suaveolens, Solanaceae). Rev. Bras. Farm. 2006; 87(2): 6364.

7. Oliveira F, Saito ML. Práticas de morfologia vegetal. São Paulo: Atheneu; 1991. p. 198.

8. Kraus JE, Arduin M. Manual básico de métodos em morfologia vegetal. Seropédica: EDUR; 1997.p. 132

9. Aragão GF. Atividade antiinflamatória, antiagregante plaquetária e efeitos centrais de alfa e beta amirina isolada de Protium heptaphyllum Aubl March [dissertação]. Ceará: Universidade Federal do Ceará; 2004.

10. Arruda, R. S. Especificidade de hospedeiros por Struthanthus aff polyanthus (Loranthacea) em uma área de cerrado, Uberlândia, Minas Gerais. [dissertação mestrado] - Universidade Federal de Uberlândia, Minas Gerais, 2004.

11. Mukhtar H, Saleem M, Murtaza I, Tarapore RS, Suh Y, Adhami VM, Johnson JJ, Siddiqui IA, Khan N, Assim Hafeez BB, Shekhani MT, Li B. Lupeol inhibits proliferation of human prostate cancer cells by targeting beta-catenin signaling. Carginogenesis. 2009; 5: 808-17. 